\title{
Faktor-Faktor Yang Mempengaruhi Penggunaan Pengisian Partograf Di BPM Swasta Wilayah Banjarmasin
}

\author{
Isnaniah ${ }^{1}$, Tri Tunggal ${ }^{2}$, Rita Kirana ${ }^{3}$ \\ Poltekkes Kemenkes Banjarmasin Jurusan Kebidanan \\ Jl. H. Mistar Cokrokusumo No. 4A, Banjarbaru, Kalimantan Selatan, 70714 \\ E-mail : Isnaniah80@gmail.com
}

\begin{abstract}
The phenomenon that occurs, states that the policy on the use of the partograph has not fully run according to the procedure. The practice midwife actually already knows the policy, but has not fully done it well. In its implementation, midwives do not use partograph completely, correctly and on time.

The results of the study were 54 respondents, 12 respondents $(22 \%)$ who lacked partograph utilization, 44 respondents (81.5\%) had good knowledge, 46 respondents $(85.2 \%)$ had a positive attitude and 40 respondents $(74.1 \%)$ had good skills. proficient, the results of the statistical test have no relationship between midwife's knowledge of partograph and the use of partograph filling and there is a meaningful relationship between attitudes and skills with the use of partographs in Banjarmasin's private BPM

The conclusion in this study is that there is no significant relationship between knowledge and the use of partographs, but there is a meaningful relationship between attitudes and skills with the use of partographs in the Banjarmasin BPM private sector and suggested BPM work area responsibilities to supervise recording and reporting
\end{abstract}

Keywords: Knowledge, Attitudes, Skills, Partographs

Copyright @ 2021 Jurnal Skala Kesehatan. Politeknik Kesehatan Banjarmasin

All rights reserved

\section{Corresponding Author:}

Isnaniah,

Poltekkes Kemenkes Banjarmasin Jurusan Kebidanan

Email : Isnaniah80@gmail.com 
Abstrak : Fenomena yang terjadi, menyatakan kebijakan tentang penggunaan partograf tersebut belum sepenuhnya berjalan sesuai prosedur. Bidan praktek sebenarnya sudah mengetahui kebijakan tersebut, namun belum sepenuhnya melakukan dengan baik. Dalam pelaksanaannya bidan tidak menggunakan partograf dengan lengkap, benar dan tepat waktu.

Metode penelitian menggunakan survey analitik dengan pendekatan cross sectional. Populasi yang digunakan dalam penelitian adalah seluruh bidan yang mendirikan BPM di Banjarmasin dan Sampel yang digunakan dalam penelitian ini adalah sebagian bidan yang mendirikan BPM di Banjarmasin yaitu 54 responden. Analisis yang digunakan adalah uji kolerasi spearman dengan $p 0,05$

Hasil penelitian dari 54 responden, 12 responden (22\%) yang kurang dalam pemanfaatan partograf,44 responden (81,5\%) berpengetahuan baik, 46 responden $(85,2 \%)$ mempunyai sikap positif dan 40 responden $(74,1 \%)$ berketerampilan mahir, Hasil uji statistic tidak ada hubungan antara pengetahuan bidan tentang partograf dengan penggunaan pengisian partograf dan ada hubungan yang bermakna antara sikap dan keterampilan dengan penggunaan partograf di BPM swasta kota Banjarmasin

Penelitian menunjukan tidak hubungan antara pengetahuan dengan penggunaan partograf tetapi ada hubungan antara sikap dan keterampilan dengan penggunaan partograf di BPM swasta Kota Banjarmasin dan disarankan kepenanggungjawab wilayah kerja BPM untuk melakukan pengawasan terhadap pencatatan dan pelaporan

Kata kunci : Pengetahuan, Sikap, Keterampilan, Partograf

\section{PENDAHULUAN}

Kematian ibu dalam persalinan disebabkan karena keterlambatan dalam mengenali risiko tinggi ibu bersalin. Menurut Fahdhy dan Chongsuvivatwong ( 2004 ) menyatakan bahwa 90\% kematian ibu terjadi pada saat persalinan karena komplikasi obstetri yang sering tidak dapat diperkirakan sebelumnya, seperti: perdarahan, partus lama dan partus tak maju. Perdarahan, partus lama dapat dicegah apabila penolong persalinan menggunakan partograf untuk mendeteksi dini penyulit persalinan sehingga keterlambatan dalam pengambilan keputusan klinik atau rujukan dapat dihindari (Sapartinah, 2011).

Salah satu upaya untuk menurunkan Angka Kematian lbu dan meningkatkan kesehatan ibu dan anak adalah cakupan pertolongan persalinan oleh tenaga kesehatan. Kompetensi bidan yang ke-empat adalah memberikan asuhan bermutu yang tinggi, tanggap terhadap kebudayaan setempat selama persalinan, mempimpin persalinan yang bersih, dan aman, menangani situasi kegawatdarutan tertentu untuk mengoptimalkan kesehatan wanita dan bayi baru lahirnya, salah satunya melalui pemantauan kemajuan persalinan normal menggunakan partograf (Setiawan, 2010).

Penerapan partograf diharapkan bahwa angka kematian maternal dan perinatal dapat diturunkan dengan bermakna sehingga mampu menunjang sistem kesehatan menuju tingkat kesejahteraan masyarakat. Kenyataannya keterampilan petugas tenaga kesehatan maupun penolong persalinan dalam penggunaan partograf masih kurang diterapkan. Penerapan partograf WHO di tujukan pada pada kehamilan normal yang direncanakan untuk persalinan pervaginam. Dengan memperhatikan garis waspada dan garis tindakan sebagai titik tolak evaluasi pertolongan persalinan sehingga diharapkan partus terlantar atau partus kasep semakin berkurang untuk dapat menurunkan angka kematian maternal dan perinatal. (Manuaba, 2010).

Menurut teori lawrance green faktor yang mempengaruhi kepatuhan bidan dalam penggunan partograf antara lain yaitu Faktor predisposisi terdiri dari pendidikan, pengetahuan, sikap, dan keterampilan/kompetensi. Faktor pendukung antara lain ketersediaan sarana prasana pelayanan kebidanan, pedoman pencatatan dan pelaporan 
kegiatan bidan. Faktor penguat dukungan sosial dan pujian serta pengawasan (Mubarak,2011).

Sikap selalu berkenaan dengan suatu objek dan sikap terhadap objek ini disertai dengan perasaan positif dan negatif, orang mempunyai sikap positif terhadap suatu objek yang bernilai pada pandangannya dan akan bersikap negatif terhadap objek yang dianggapnya tidak bernilai dan atau merugikan (Slameto, 2010 : 188-189). Sehingga sikap juga mempengaruhi kepatuhan bidan dalam penggunaan partograf.

Penggunaan partograf secara rutin oleh bidan dapat memastikan bahwa ibu dan bayinya mendapatkan asuhan persalinan secara aman, adekuat dan tepat waktu, serta membantu mencegah terjadinya penyulit yang dapat mengancam keselamatan jiwa mereka (JNPKR,2008 : 55). Fenomena yang terjadi, menyatakan kebijakan tentang penggunaan partograf tersebut belum sepenuhnya berjalan sesuai prosedur. Bidan praktek sebenarnya sudah mengetahui kebijakan tersebut, namun belum sepenuhnya melakukan dengan baik. Dalam pelaksanaannya bidan tidak menggunakan partograf dengan lengkap, benar dan tepat waktu.

Berdasarkan latar belakang di atas, peneliti tertarik untuk mengkaji permasalahan tersebut kedalam sebuah penelitian yang berjudul "Faktor-Faktor Yang Mempengaruhi Penggunaan Pengisian Partograf Pada BPM Swasta di Banjarmasin Pada Tahun 2018”.

\section{BAHAN DAN METODE}

Jenis penelitian yang digunakan Penelitian ini menggunakan rancangan penelitian survey analitik dengan pendekatan adalah Cross Sectional . dengan jumlah sampel 54 orang

Pendekatan pada penelitian ini yaitu dengan melakukan pengukuran atau pengamatan pada saat bersamaan antara pengetahuan, sikap, keterampilan dan penggunaan pengisian partograf. Instrument yang digunakan untuk mengungkapkan variabel bebas dan terikat adalah kuesioner dan checklist tentang penggunaan pengisian partograf. Rancangan penelitian ini digunakan untuk mengetahui faktor-faktor yang mempengaruhi dalam penggunaan pengisian partograf di BPM Swasta Banjarmasin tahun 2018.

\section{HASIL DAN PEMBAHASAN}

a. Penggunaan Patograf

Distribusi Frekuensi Penggunaan Pengisian Partograf pada Bidan di BPM Swasta di Banjarmasin Pada Tahun 2018

\begin{tabular}{c|c|c}
\hline Variabel & Frekuensi & $\%$ \\
\hline Baik & 42 & 77.8 \\
\hline Kurang & 12 & 22.2 \\
\hline Total & 54 & 100,0 \\
\hline Sumber : Data Sekunder &
\end{tabular}

Tabel diatas menunjukan bahwa dari 54 BPM Swasta di Banjarmasin Tahun 2018, ada 12 orang $(22,2 \%)$ yang masih kurang dalam pemanfaatan partograf. 
b. Pengetahuan

Distribusi Frekuensi pengetahuan bidan tentang penggunaan pengisian partograf pada BPM Swasta di Banjarmasin Pada Tahun 2018

\begin{tabular}{l|c|c}
\hline \multicolumn{1}{c|}{ Variabel } & Frekuensi & $\%$ \\
\hline Baik & 44 & 81,5 \\
\hline Cukup & 10 & 18,5 \\
\hline Total & 54 & 100 \\
\hline Sumber : Data Sekunder & \multicolumn{2}{|l}{}
\end{tabular}

Tabel diatas menunjukan bahwa dari 54 BPM Swasta di Banjarmasin Tahun 2018, paling banyak BPM Swasta yang berpengetahuan baik, yaitu 44 orang $(81,5 \%)$.

c. Sikap

Distribusi Frekuensi Sikap bidan tentang penggunaan pengisian partograf pada BPM Swasta di Banjarmasin Pada Tahun 2018

\begin{tabular}{l|c|c}
\hline \multicolumn{1}{c|}{ Variabel } & Frekuensi & $\%$ \\
\hline Positif & 46 & 85.2 \\
\hline Negatif & 8 & 14.8 \\
\hline Total & 54 & 100,0 \\
\hline
\end{tabular}

Sumber : Data Sekunder

Tabel diatas menunjukan bahwa dari 54 BPM Swasta di Banjarmasin Tahun 2018, paling banyak sikap positif yaitu 46 orang (85.2\%).

d. Keterampilan

Distribusi Frekuensi pengetahuan bidan tentang penggunaan pengisian partograf pada BPM Swasta di Banjarmasin Pada Tahun 2018

\begin{tabular}{l|c|c}
\hline \multicolumn{1}{c|}{ Variabel } & Frekuensi & $\%$ \\
\hline Mahir & 40 & 74.1 \\
\hline Mampu & 11 & 20.4 \\
\hline Awal & 3 & 5.6 \\
\hline Total & 54 & 100 \\
\hline
\end{tabular}

Sumber : Data Sekunder

Tabel diatas menunjukan bahwa dari 54 BPM Swasta di Banjarmasin Tahun 2018, paling banyak BPM Swasta yang berketerampilan mahir, yaitu 40 orang $(74,1 \%)$. 
e. Analisa Bivariat

Hubungan pengetahuan bidan tentang partograf dengan penggunaan pengisian partograf pada BPM Swasta di Banjarmasin pada Tahun 2018.

\begin{tabular}{|c|c|c|c|c|c|c|}
\hline \multirow{3}{*}{ Pengetahuan } & \multicolumn{4}{|c|}{ Penggunaan Patograf } & \multirow{3}{*}{ Total } & \multirow{3}{*}{$\%$} \\
\hline & \multicolumn{2}{|c|}{ Baik } & \multicolumn{2}{|c|}{ Kurang } & & \\
\hline & $\mathrm{F}$ & $\%$ & $\mathrm{~F}$ & $\%$ & & \\
\hline Baik & 37 & $84.1 \%$ & 7 & $15.9 \%$ & 44 & 100.0 \\
\hline Cukup & 5 & $50.0 \%$ & 5 & $50.0 \%$ & 10 & 100.0 \\
\hline Total & 42 & $77.8 \%$ & 12 & $33,3 \%$ & 54 & 100.0 \\
\hline Continuity Correctio & \multicolumn{4}{|c|}{$\rho=0.055$} & \multicolumn{2}{|c|}{$\alpha=0.05$} \\
\hline
\end{tabular}

tabel diatas menyajikan data dari 44 orang yang memiliki Pengetahuan baik sebanyak 7 orang (15.9\%) yang masih kurang dalam menggunakan patograf dan dari 10 orang yang berpengetahuan cukup ada 5 orang (50.0\%) yang menggunakan patograf dengan baik.

Berdasarkan analisa data dengan uji statistik chi-square diketahui nilai $\rho=0,055$ $\leq \alpha=0.05$, yaitu artinya bahwa jika nilai signifikan berada di atas dengan 0.05 maka hipotesa ditolak, kesimpulan secara statistic tidak ada hubungan antara pengetahuan bidan tentang partograf dengan penggunaan pengisian partograf pada BPM Swasta di Banjarmasin pada Tahun 2018.

Hubungan sikap bidan tentang partograf dengan penggunaan pengisian partograf pada BPM Swasta di Banjarmasin pada Tahun 2018.

\begin{tabular}{|c|c|c|c|c|c|c|}
\hline \multirow{3}{*}{ Sikap } & \multicolumn{4}{|c|}{ Penggunaan Patograf } & \multirow{3}{*}{ Total } & \multirow{3}{*}{$\%$} \\
\hline & \multicolumn{2}{|c|}{ Baik } & \multicolumn{2}{|c|}{ Kurang } & & \\
\hline & $\mathrm{F}$ & $\%$ & $\mathrm{~F}$ & $\%$ & & \\
\hline Positif & 39 & $84.8 \%$ & 7 & $15.2 \%$ & 46 & 100.0 \\
\hline Negatif & 3 & $37.5 \%$ & 5 & $62.5 \%$ & 8 & 100.0 \\
\hline Total & 42 & $77.8 \%$ & 12 & $22,2 \%$ & 54 & 100.0 \\
\hline Continuity Corre & \multicolumn{4}{|c|}{$\rho=0.012$} & \multicolumn{2}{|c|}{$\alpha=0.05$} \\
\hline
\end{tabular}

Tabel diatas menyajikan data dari 46 orang yang memiliki sikap positif sebanyak 7 orang (15.2\%) yang masih kurang dalam menggunakan patograf dan dari 8 orang yang bersikap negatif ada 3 orang (62.5\%) yang menggunakan patograf dengan baik.

Berdasarkan analisa data dengan uji statistik chi-square diketahui nilai $\rho=0,012$ $\leq \alpha=0.05$, yaitu artinya bahwa jika nilai signifikan berada di bawah atau sama dengan 0.05 maka hipotesa diterima, kesimpulan secara statistic ada hubungan antara sikap bidan tentang partograf dengan penggunaan pengisian partograf pada BPM Swasta di Banjarmasin pada Tahun 2018. 
Hubungan keterampilan bidan tentang partograf dengan penggunaan pengisian partograf pada BPM Swasta di Banjarmasin pada Tahun 2018.

\begin{tabular}{|c|c|c|c|c|c|c|}
\hline \multirow{3}{*}{ Keterampilan } & \multicolumn{4}{|c|}{ Penggunaan Patograf } & \multirow{3}{*}{ Total } & \multirow{3}{*}{$\%$} \\
\hline & \multicolumn{2}{|c|}{ Baik } & \multicolumn{2}{|c|}{ Kurang } & & \\
\hline & $\mathrm{F}$ & $\%$ & $\mathrm{~F}$ & $\%$ & & \\
\hline Mahir & 38 & $95.0 \%$ & 2 & $5.0 \%$ & 40 & 100.0 \\
\hline Mampu & 4 & $36.4 \%$ & 7 & $63.6 \%$ & 11 & 100.0 \\
\hline Awal & 0 & $0 \%$ & 3 & $100.0 \%$ & 3 & 100.0 \\
\hline Total & 42 & $77.8 \%$ & 12 & $33,3 \%$ & 54 & 100.0 \\
\hline Pearson Chi Square & \multicolumn{4}{|c|}{$\rho=0.000$} & $\alpha=0,05$ & \\
\hline
\end{tabular}

Tabel diatas menyajikan data dari 40 orang yang memiliki keterampilan mahir sebanyak 2 orang (5.0\%) yang kurang mahir dalam menggunakan patograf, dari 11 orang yang memiliki keterampilan mampu ada 7 orang (63.6\%) yang masih kurang dalam menggunakan patograf, dan dari 3 orang yang memiliki keterampilan awal sebanyak 3 orang (100.0\%) yang kurang dalam melakukan pengisian patograf.

Berdasarkan analisa data dengan uji statistik chi-square diketahui nilai $\rho=0,000$ $\leq \alpha=0.05$, yaitu artinya bahwa jika nilai signifikan berada di bawah atau sama 0.05 maka hipotesa diterima, kesimpulan secara statistic ada hubungan antara keterampilan bidan tentang partograf dengan penggunaan pengisian partograf pada BPM Swasta di Banjarmasin pada Tahun 2018.

\section{PEMBAHASAN}

1. Penggunaan Partograf

Partograf adalah alat bantu yang digunakan selama persalinan. Partograf atau partogram adalah metode grafik untuk merekam kejadian pada perjalanan persalinan (Sarwono, 2009). Menurut Sarwono (2009), menyatakan World Health Organization (WHO, 2000) telah memodifikasi partograf agar lebih sederhana dan lebih mudah digunakan. Fase laten telah dihilangkan, dan pencatatan pada partograf dimulai dari fase aktif ketika pembukaan serviks $4 \mathrm{~cm}$.

Penelitian ini menunjukan bahwa terdapat banyak bidan yang menggunakan partograf dengan baik yaitu sebanyak 42 orang dari 54 bidan. Hal ini dikarenakan program pemerintah yang baik, dimana bidan dituntut untuk membuat pelaporan dan pencatatan Kesahatan Ibu dan Anak (KIA).

Tetapi masih ada 12 orang bidan yang kurang dalam pemanfaatan partograf dikarenakan banyak factor seperti pendidikan, pengetahuan, sikap, keterampilan. Hal ini sesuai dengan teori lawrance green faktor yang mempengaruhi kepatuhan bidan dalam penggunan partograf antara lain yaitu Faktor predisposisi terdiri dari pendidikan, pengetahuan, sikap, dan keterampilan/ kompetensi. Faktor pendukung antara lain ketersediaan sarana prasana pelayanan kebidanan, pedoman pencatatan dan pelaporan kegiatan bidan. Faktor penguat dukungan sosial dan pujian serta pengawasan (Mubarak,2011).

2. Pengetahuan

Berdasarkan tabel frekuensi pengetahuan menunjukan bahwa dari 54 BPM Swasta di Banjarmasin Tahun 2018, paling banyak BPM Swasta yang berpengetahuan baik, yaitu 44 orang $(81,5 \%)$.

Notoatmodjo (2008) membahas pengetahuan merupakan hasil dari tahu, dan ini terjadi setelah orang melakukan penginderaan terhadap suatu objek tertentu. Penginderaan ini terjadi melalui panca indera manusia, yaitu indera penglihatan, pendengaran, penciuman, rasa dan raba. Sebagaian besar pengetahuan manusia 
diperoleh melalui mata dan telinga. Pengetahuan atau kognitif merupakan domain yang sangat penting untuk terbentuknya perilaku seseorang. Pengetahuan secara rinci tentang penggunaan partograf merupakan syarat mutlak bagi penolong persalinan. Seperti hasil - hasil penelitian yang pernah dilakukan menyatakan bahwa pengetahuan provider kesehatan tentang partograf berhubungan dalam proses pncatatan dan kepatuhan mengisi partograf.

Penelitian ini menunjukan bahwa dari 54 ada 44 orang bidan di BPM Swasta Banjarmasin yang berpengetahuan baik dan sisanya yang berpengetahuan cukup. Hal ini dikarenakan bidan hampir semua sudah mendapatkan pelatihan untuk pengisian partograf.

3. Sikap

Berdasarkan tabel Frekuensi Sikap menunjukan bahwa dari 54 BPM Swasta di Banjarmasin Tahun 2018, paling banyak sikap positif yaitu 46 orang (85.2\%).

Notoatmodjo (2007) membahas tentang sikap merupakan reaksi atau respon yang masih tertutup dari seseorang terhadap suatu stimulasi atau objek. Sikap tidak dapat langsung dilihat, tetapi hanya dapat ditafsirkan terlebih dahulu dari perilaku yang tertutup. Sikap merupakan kesiapan untuk bereaksi terhadap objek di lingkungan tertentu sebagai suatu penghayatan terhadap objek.

Penelitian ini menunjukan bahwa dari 54 ada 46 orang bidan di BPM Swasta Banjarmasin yang bersikap positif . Hal ini menunjukan bahwa bidan di BPM Swasta Wilayah Banjarmasin sudah sangat baik. Hal ini dikarenakan kesadaran yang tinggi bahwa pentingnya penggunaan partograf.

4. Keterampilan

Berdasarkan tabel 4.4 menunjukan bahwa dari 54 BPM Swasta di Banjarmasin Tahun 2018, paling banyak BPM Swasta yang berketerampilan mahir, yaitu 40 orang $(74,1 \%)$.

Menurut Alwi, dkk (2005) Perilaku dalam bentuk praktik yang sudah konkrit berupa perbuatan terhadap situasi atau rangsangan dari luar. Menurut Notoatmodjo (2007), faktor yang mempengaruhi keterampilan seseorang dalam melakukan sebuah tindakan, sebagai berikut pengetahuan, sikap, psikomotor, dan edukasi.

Penelitian ini menunjukan bahwa dari 54 ada 40 orang bidan di BPM Swasta Banjarmasin yang memeliki keterampilan mahir . Hal ini dikarenakan rata-rata bidan di BPM Swasta Banjarmasin sudah mendapatkan pelatihan dan edukasi dari berbagai seminar tentang partograf. Program pemerintah juga menuntut untuk kelengkapan pencatatan dan pelaporan sehingga mau tidak mau bidan sudah terbiasa dalam penggunaan partograf.

5. Hubungan Tingkat Pengetahuan dengan Penggunaan Partograf

Berdasarkan tabel Pengetahuan dan pengunaan partograf menyajikan data dari 44 orang yang memiliki Pengetahuan baik sebanyak 7 orang (15.9\%) yang masih kurang dalam menggunakan patograf dan dari 10 orang yang berpengetahuan cukup ada 5 orang $(50.0 \%)$ yang menggunakan patograf dengan baik.

Berdasarkan analisa data dengan uji statistik chi-square diketahui nilai $\rho=0,055$ $\leq \alpha=0.05$, yaitu artinya bahwa jika nilai signifikan berada di atas dengan 0.05 maka hipotesa ditolak, kesimpulan secara statistik tidak ada hubungan antara pengetahuan bidan tentang partograf dengan penggunaan pengisian partograf pada BPM Swasta di Banjarmasin pada Tahun 2018.

Banyak faktor dalam penggunaan partograf bukan hanya sekedar pengetahuan, tetapi juga sikap, pendidikan, keterampilan, pujian dan dukungan social, serta pengawasan (Yisma.dkk, 2013).

Penelitian ini menunjukan bahwa tidak ada hubungan antara pengetahuan dengan penggunaan partograf dikarenakan banyak faktor yang mempengaruhi. Tetapi dari hasil analisis memang tidak ada bidan yang berpengatahuan kurang. 
6. Hubungan Sikap dengan Penggunaan Partograf

Berdasarkan tabel sikap dan pengunaan partograf menyajikan data dari 46 orang yang memiliki sikap positif sebanyak 7 orang (15.2\%) yang masih kurang dalam menggunakan patograf dan dari 8 orang yang bersikap negatif ada 3 orang (62.5\%) yang menggunakan patograf dengan baik.

Berdasarkan analisa data dengan uji statistik chi-square diketahui nilai $\rho=0,012$ $\leq \alpha=0.05$, yaitu artinya bahwa jika nilai signifikan berada di bawah atau sama dengan 0.05 maka hipotesa diterima, kesimpulan secara statistic ada hubungan antara sikap bidan tentang partograf dengan penggunaan pengisian partograf pada BPM Swasta di Banjarmasin pada Tahun 2018.

Faktor-faktor yang mempengaruhi dalam penggunaan partograf antara lain pengetahuan, sikap, pendidikan, keterampilan, pujian dan dukungan social, serta pengawasan (Yisma.dkk, 2013).

Faktor sikap, ada beberapa yang tidak pernah menerapkan patograf pada setiap melakukan pertolongan persalinan dengan alasan malas dan tidak ada waktu. Hal tersebut akan mempengaruhi seseorang dalam bersikap. Sikap merupakan reaksi atau respon seseorang yang masih tertutup terhadap suatu stimulus atau objek tertentu, yang sudah melibatkan faktor pendapat dan emosi yang bersangkutan (Notoatmodjo, 2010 : 52). Sikap menentukan bagaimana individu bereaksi terhadap situasi serta menentukan apa yang dicari individu dalam kehidupannya. Sikap selalu berkenaan dengan suatu objek dan sikap terhadap objek ini disertai dengan perasaan positif dan negatif, orang mempunyai sikap positif terhadap suatu objek yang bernilai pada pandangannya dan akan bersikap negatif terhadap objek yang dianggapnya tidak bernilai dan atau merugikan (Slameto, 2010 : 188-189). Sehingga sikap juga mempengaruhi kepatuhan bidan dalam penggunaan partograf.

Penelitian ini menunjukan bahwa ada hubungan antara sikap dengan penggunaan partograf. Hal ini sesuai dengan teori Yisma,dkk (2013) dan penelitian lainnya.

7. Hubungan Keterampilan dengan Penggunaan Partograf

Berdasarkan tabel Keterampilan dan pengunaan partograf menyajikan data dari 40 orang yang memiliki keterampilan mahir sebanyak 2 orang $(5.0 \%)$ yang kurang mahir dalam menggunakan patograf, dari 11 orang yang memiliki keterampilan mampu ada 7 orang (63.6\%) yang masih kurang dalam menggunakan patograf, dan dari 3 orang yang memiliki keterampilan awal sebanyak 3 orang $(100.0 \%)$ yang kurang dalam melakukan pengisian patograf.

Berdasarkan analisa data dengan uji statistik chi-square diketahui nilai $\rho=0,000$ $\leq \alpha=0.05$, yaitu artinya bahwa jika nilai signifikan berada di bawah atau sama 0.05 maka hipotesa diterima, kesimpulan secara statistic ada hubungan antara keterampilan bidan tentang partograf dengan penggunaan pengisian partograf pada BPM Swasta di Banjarmasin pada Tahun 2018.

Faktor-faktor yang mempengaruhi dalam penggunaan partograf antara lain pengetahuan, sikap, pendidikan, keterampilan, pujian dan dukungan social, serta pengawasan (Yisma.dkk, 2013).

Penelitian ini menunjukan bahwa ada hubungan antara keterampilan dengan penggunaan partograf. Hal ini sesuai dengan Menurut teori lawrance green faktor yang mempengaruhi kepatuhan bidan dalam penggunan partograf antara lain yaitu Faktor predisposisi terdiri dari pendidikan, pengetahuan, sikap, dan keterampilan/kompetensi. Faktor pendukung antara lain ketersediaan sarana prasana pelayanan kebidanan, pedoman pencatatan dan pelaporan kegiatan bidan. 


\section{KESIMPULAN}

Berdasarkan hasil pembahasan pada penelitian yang dilakukan di Wilayah Kerja BPM Swasta Banjarmasin Tahun 2018, dengan jumlah responden sebanyak 54 orang, dapat disimpulkan sebagai berikut :

1. Bidan yang masih kurang dalam pemanfaatan partograf ada 12 orang $(22,2 \%)$.

2. Bidan yang paling banyak berpengetahuan baik, yaitu 44 orang $(81,5 \%)$.

3. Bidan yang paling banyak sikap positif yaitu 46 orang $(85.2 \%)$.

4. Bidan paling banyak yang berketerampilan mahir, yaitu 40 orang $(74,1 \%)$.

5. Tidak Ada hubungan yang bermakna antara pengetahuan dengan penggunaan partograf.

6. Ada hubungan yang bermakna antara Sikap dengan penggunaan partograf.

7. Ada hubungan yang bermakna antara Keterampilan dengan penggunaan partograf.

\section{DAFTAR PUSTAKA}

1. Anggraini, Sri. (2010) Pengaruh Motivasi Belajar dan Metode Pembelajaran Studi Kasus Terhadap Prestasi Belajar Penggunaan Partograf Mahasiswa Akademi Kebidanan di Surakarta. Bersumber dari: $<$ http://repository.unhas.ac.id> [Diakses tanggal 16 September 2017]

2. Anitah, Sri dW., dkk. (2007) Strategi Pembelajaran di SD. Jakarta: Universitas Terbuka

3. Aprilia, D. (2014) Efektifitas Metode Brainstorming dan Metode Ceramah Terhadap Penggunaan Partograf Pada Mahasiswa Semester II Kebidanan (DIII) STIKES William Booth Surabaya. Skripsi. Universitas Kadiri

4. Arikunto, S. (2006) Prosedur Penelitian Suatu Pendekatan Praktik. Edisi Revisi V. Jakarta: Rineka Cipta

5. Chunningham, F. Gary, et al. (2012) Obstetri Williams. Volume 2, Edisi 23. Jakarta. EGC.

6. Depdiknas, (2008) Kumpulan Pembelajaran/pendamping. Bersumber dari: $<$ http.www.media.diknas. go.id> [Diunduh Tanggal 15 Januari 2015]

7. Depdiknas. (2008) Strategi Pembelajaran dan Pemilihannya. Jakarta: Direktorat Jendral Peningkatan Mutu Pendidik dan Tenaga Kependidikan.

8. JNPK-KR. (2008) Pelatihan Klinik Asuhan Persalinan Normal : Asuhan Esensial, Pencegahan dan Penanggulangan Segera Komplikasi Persalinan dan Bayi Baru Lahir. Jakarta

9. Hidayat, A. Aziz Alimul. (2010) Metode Penelitian Kesehatan Paradigma Kuantitatif. Surabaya. Health Books Publishing.

10. Nazir. (2005) Metode Penelitian. Jakarta. Ghalia Indonesia.

11. Notoatmodjo. (2010) Metodologi Penelitian Kesehatan. Jakarta : Rineka Cipta

12 Tim Pengembang IImu Pendidikan FIP-UPI. (2007) IImu dan Aplikasi Pendidikan. Jakarta: IMTIMA 